\title{
Penerapan Metode Pakem Terhadap Prestasi Belajar Qur'an Hadits Kelas VI \\ MI NW Karang Baru Kecamatan Wanasaba Kabupaten Lombok Timur
}

Tahun Pelajaran 2015/2016

\author{
Asbullah Muslim
}

\begin{abstract}
ABSTRAK
Penelitian pengembangan ini bertujuan untuk mengembangkan penerapan Metode Pakem kelas VI MI NW Karang Baru Tahun Pelajaran 2015/2016 Penelitian ini merupakan penelitian dan pengembangan (Research and Development). Penelitian pengembangan ini menggunakan model pengembangan Borg and Gall yang dilakukan dengan lima tahapan, yaitu analisis kebutuhan, perencanaan, pengembangan draf produk, uji coba lapangan, revisi produk. Metode pengumpulan data yang digunakan dalam penelitian pengembangan ini adalah angket respon siswa dan tes hasil belajar siswa.
\end{abstract}

\section{Kata Kunci: Prestasi, Belajar, Metode Pakem}

\begin{abstract}
Singer development research aims to develop the application review methods Pakem Class VI MI NW Karang Baru Academic Year 2015/2016 Research Singer is a Research and Development (Research and Development). Singer Research Development Model development using the Borg and Gall What do WITH the five stages, ie requirement analysis, planning, DRAFT Product Development, Field trials, product revision. Data collection methods used Yang hearts Development Research Singer Was questionnaire responses Students and Students learn the test results.
\end{abstract}

Keyword: Achievement, Learning, Methods Pakem

\section{PENDAHULUAN}

\section{A. Latar Belakang}

Manusia sebagai mahluk sosial yang memiliki sifat dan tingkah laku yang kadang kala dapat dipengaruhi oleh situasi dan kondisi, maka dibutuhkan padanya pembentukan keperibadian sehingga kita sebagai manusia selalu berada pada rel manapun, baik yang datang diri kita meupun yang datangnya dari luar. Masalah Qur'an 
Hadits merupakan suatu masalah yang sangat mendasar bagai setiap pribadi muslimin dalam kehidupan sehari-hari, dan dengan Qur'an Hadits mampu mewarnai segala sikap dan prilaku baik hubungan sesama manusia atau lingkungan kita terlebih lagi hubungan dengan Allah SWT. yang sempurna menuju keselamatan dunia dan akhirat.

Dalam usaha pembentukan pendidikan akhlak yang mantap dan terpuji harus di pertimbangkan nilai-nilai manakah yang harus di tanamkan kepada anak-anak didik sejak dini sebagai modal serta benteng dalam hidup dan kehidupannya. Islam sebagai agama wahyu yang sumber ajarannya adalah al- Qur'an dan al-Hadist inilah yang harus di pedomani sepanjang hayat dan berlaku di mana saja dan kapan saja. Sebagaimana ayat dalam Q.S. Az-Zumar ayat 9 mengatakan : "Katakanlah: "Adakah sama orang-orang yang mengetahui dengan orang-orang yang tidak mengetahui?" Sesungguhnya orang yang berakallah yang dapat menerima pelajaran. ${ }^{1}$

Sejalan dengan itu Rasulullah SAW bersabda tentang wajibnya menuntut ilmu :

$$
\text { أ طلب العلم فريضة على كل مسلم ( متفق عليه ) }
$$

Artinya : Tuntutlah ilmu itu wajib bagi kaum muslimin ${ }^{2}$

Pembelajaran PAKEM akan sangat membantu guru dalam pembelajaran yang dijalaninya. Karena kalau kita berbicara tentang pembelajaran PAKEM, tidak terlepas dari peran guru sebagai motVIator dalam memberikan dorongan semangat kepada peserta didik. Karena dalam pembelajaran PAKEM, disini peserta didik lebih aktif dari gurunya. Guru hanya memberikan pengarahan dan tuntunan saja, selebihnya murid yang bekerja menyelesaikannya. Pembelajaran PAKEM selalu harus tersedia media pembelajaran. Walaupun alat peraga sederhana. Terjadi intraksi timbal balik anatara guru dan siswa. Siswa lebih dominant aktif dalam pembelajaran dan adanya manfaat atau kesan khususnya bagi para siswa setelah mengikuti pelajaran tersebut. Adapun tujuan dan pembelajaran PAKEM itu sendiri adalah agar pembelajara tidak pakum, menonton, dan siswa lebih termotvasi dalam belajar. Disini guru dituntut juga untuk kreatif dalam mencari media pembelajaran.. ${ }^{3}$

Pengajar harus selektif dalam memilih dan memikirkan moral dan tingkah laku yang harus dikembangkan dan dibina pada anak didik, karena hal ini tidak cukup hanya

\footnotetext{
${ }^{1}$ Depag RI, Al-Qur'an dan Terjemah, (CV. Samara Mandiri, Jakarta, 2007), hlm.811

${ }^{2}$ HR. At-Tarmizi, Terjemah Ihiya' Ulumuddin, (CV Asy Syifa' Semarang, 1992) hlm. 143

${ }^{3}$ Rusyanto Hamid, Cara Belajar Menyenangkan, (Depdikbud, Jakarta, 2001), hal. 20
} 
mengisi ilmu pengetahuan sebanyak-banyaknya kepada anak didik atau hanya menanamkan segi intlektualnya saja. Oleh karena itu pendidikan moral dan pembentukan keperibadian hendaknya harus ada dalam lembaga pendidikan sehingga nantinya mereka mampu menyesuaikan diri dengan lingkungan dan mengembangkan dirinya ditengah-tengah masyarakat. Dengan harapan semoga anak didik dapat menentukan bagaimana selayaknya dalam mengadakan hubungan dengan manusia di lingkungan sekitar. Juga dengan hubungan Allah SWT. Sehinggga kebahagian lahir dan bathin dari dunia sampai akhirat dapat tercapai.

Mengingat pentingnya penelitian di MI NW Karang Baru dalam menentukan kepribadian anak didikan maka penulis sangat tertarik dan coba memahami serta mendalaminya melalui judul penelitian “Penerapan Metode Pakem Terhadap Prestasi Belajar Qur'an Hadits Kelas VI MI NW Karang Baru Kecamatan Wanasaba Kabupaten Lombok Timur Tahun Pelajaran 2015/2016".

\section{B. Rumusan Masalah}

Berpijak dari apa yang penulis paparkan dalam latar belakang tersebut ada beberapa hal yang penulis jadikan sebagai rumusan masalah yaitu :

1 Bagaimanakah Penerapan Metode Pakem Terhadap Prestasi Belajar Qur'an Hadits Kelas VI MI NW Karang Baru Kecamatan Wanasaba Kabupaten Lombok Timur Tahun Pelajaran 2015/2016?

2 Bagaimanakah kendala-kendala Penerapan Metode Pakem Terhadap Prestasi Belajar Qur'an Hadits Kelas VI MI NW Karang Baru Kecamatan Wanasaba Kabupaten Lombok Timur Tahun Pelajaran 2015/2016?

3 Bagaimana upaya-upaya yang dilakukan dalam Penerapan Metode Pakem Terhadap Prestasi Belajar Qur'an Hadits Kelas VI MI NW Karang Baru Kecamatan Wanasaba Kabupaten Lombok Timur Tahun Pelajaran 2015/2016?

\section{METODE PENELITIAN}

\section{A. Pendekatan Penelitian}

Dengan memahami dan menganalisis permasalahan yang ada, maka dalam penelitian ini memakai penelitian kualitatif yang lebih banyak menggunakan logika serta penjelasan-penjelasan serta data-data dari sumber yang diteliti dilapangan. Menurut Borgan dan Taylor dalam bukunya Moleong mendefinisikan "Penelitian kualitatif sebagai 
prosedur penelitian yang menghasilkan data deskriftif berupa kata-kata tertulis atau lisan dari orang-orang dan prilaku dari orang yang dapat diamati". ${ }^{1}$

Sedangkan Kirk dan Muller dalam Moleong mendefinisikan bahwa "Penelitian kualitatif adalah tradisi tertentu dalam ilmu pengetahuan sosial yang secara fundamental yang bergantung pada pengamatan manusia dalam kawasannya sendiri dan berhubungan dengan orang-orang tertentu dalam bahasanya dan pristilahannya. ${ }^{2}$

Penelitian kualitatif merupakan suatu pendekatan yang berdasarkan pada penjelasan dan data-data yang diambil langsung dari obyek penelitian secara menyeluruh.

Dalam penelitian ini menggunakan metode kualitatif dengan alasan pertama, metode kualitatif lebih mudah mengadakan penelitian yang hanya berbentuk penjelasan dan data-data. Kedua, metode ini lebih mudah menyajikan hasil penelitian secara langsung antara peneliti dengan responden. Dan ketiga, metode ini lebih peka terhadap pelaksanaan pembelajaran Qur'an Hadits. Sedangkan masa penelitian ini tanggal 30 Juni s/d 30 September 2015

\section{B. Sumber Data}

Menurut Suharsimi Arikunto "yang dimaksud dengan sumber data dalam penelitian adalah subyek darimana dapat di peroleh". 4 Sedangkan menurut Lopland dalam Moleong menyebutkan "Sumber data utama dalam penelitian kualitatif berupa kata-kata dan tindakan, selebihnya adalah data tambahan seperti dokumen dan lain-lain". 5

Untuk mendapatkan sejumlah data dan dokumen-dokumen yang diperlukan, tentu peneliti bertemu langsung dengan orang-orang yang dimintai keterangan sehubungan dengan obyek penelitian yang dimaksud, di antaranya adalah : Kepala Madrasah dan Komite dan Bapak Wakil Kepala Madrasah dan siswa siswi MI NW Karang Baru Kecamatan Wanasaba Lombok Timur TP. 2015/2016.

\section{Prosedur Pengumpulan Data}

Adapun prosedur yang digunakan dalam mengumpulkan data-data antara lain :

\section{Metode Observasi}

Metode observasi sesungguhnya suatu strategi pengumpulan data dalam bentuk sederhana, praktis dan tidak terlalu banyak menghabiskan dana dan

\footnotetext{
${ }^{1}$ Moleong Lexy J. Metodologi "Penelitian Kualitatif", (Bandung : Rosdakarya Offset, 2002), hal. 3

${ }^{2}$ Ibid, hal. 3

${ }^{4}$ Suharsimi Atikunto, "Prosedur Penelitian Suatu Pendekatan praktik", (Rineka Cipta, Jakarta, 2002). hal. 107.

${ }^{5}$ Ibid, hal.157
} 
waktu karena pelaksanaannya langsung dengan pengamatan terhadap pristiwapristiwa yang ada di lapangan.

Menurut Margono bahwa metode observasi merupakan pengamatan dan pencatatan secara sistimatis terhadap gejala yang tampak pada obyek penelitian. Jadi metode pengumpulan data dengan cara terjun langsung ke lapangan untuk mengamati berbagai pristiwa sekaligus mengadakan pencatatan secara sistimatis terhadap segala hal yang di temukan agar data yang di peroleh tidak dilupakan. ${ }^{4}$

Dalam menggunakan observasi, yaitu pengambilan data dengan mempergunakan indra penglihatan (mata) dan menyelidiki obyek yang sedang di teliti dengan harapan agar mendapat hasil yang lebih akurat.

1. Keadaan Gedung MI NW Karang Baru Kecamatan Wanasaba Tahun Pelajaran $2015 / 2016$

2. Pelaksanaan Pembelajaran Qur'an Hadits di MI NW Karang Baru Kecamatan Wanasaba Tahun Pelajaran 2015/2016

3. Keadaan Sarana dan guru di MI NW Karang Baru Tahun Pelajaran 2015/2016 2. Metode Dokumentasi

Metode Dokumentasi untuk mencari data mengenai hal-hal atau variabel berupa catatan, transkrip, buku, surat kabar, majalah, prasasti, notulen rapat, leger, agenda dan sebagainya ${ }^{5}$

Sedangkan menurut Guba dan Lincoln dalam Moleong 6 mendefinisikan " Dokumentasi adalah setiap bahan tertulis ataupun film. Mengumpulkan data melalui peninggalan tertulis, seperti arsip-arsip dan termasuk juga buku-buku tentang pendapat, teori, dalil atau hukum-hukum dan lain-lain yang berhubungan dengan masalah penelitian. ${ }^{7}$

Adapun data yang diperoleh melalui metode ini antara lain : Data Keadaan Guru, Struktur Organisasi MI NW Karang Baru Kecamatan Wanasaba, Data Keadaan Gedung MI NW Karang Baru Kecamatan Wanasaba dan lain-lain.

3. Metode Interview

\footnotetext{
${ }^{4}$ Margono, S. "Metodologi Penelitian Pendidikan", (Jakarta Rineka Cipta, Jakarta, 2004), hal. 158

${ }^{5}$ Suharsimi Arikunto. "Prosedur Penelitian Suatu Pendekatan Praktek, Edisi Revisi". (Jakarta : Rineka Cipta 2002). hal. 206.

${ }^{6} \mathrm{Ibid}$, hal.161

${ }^{7}$ Ibid, hal.181
} 
Wawancara adalah alat pengumpul informasi dengan cara mengajukan sejumlah pertanyaan secara lisan untuk di jawab sacara lisan pula 8 Wawancara adalah " Percakapan dengan maksud tertentu di lakukan oleh dua belah pihak yaitu pewawancara dan yang di wawancarai. ${ }^{9}$ Yang dijadikan obyek wawancara yaitu Guru Qur'an Hadits, dan Kepala Madrasah. Hubungannya dengan metode ini, dapat disimpulkan data antara lain : Latar belakang berdirinya MI NW Karang Baru Kecamatan Wanasaba, Pelaksanaan pembelajaran Qur'an Hadits terhadap pembinaan (akhlak siswa), dan problematika yang di hadapi dalam pembinaan kepribadian anak didik.

\section{Analisa Data}

Menurut Bagdan dan Taylor dalam bukunya Moleong mendefinisikan analisis data "sebagai proses yang merinci usaha secara formal untuk menentukan tema dan merumuskan hipotesis (Ide) berdasarkan data dan sebagai usaha untuk memberikan bantuan pada tema dan hipotesis itu". ${ }^{10}$

Setelah memperoleh data yang valid, kemudian dianalisis dengan tiga cara, yaitu :

1. Persiapan

Kegiatan dalam langkah persiapan ini antara lain :

a. Memeriksa kembali data yang di peroleh, apakah data tersebut dapat dipertanggung jawabkan atau tidak.

b. Memeriksa kelengkapan data, yaitu mengecek data-data yang telah dikumpulkan dari lokasi penelitian serta meneliti data-data yang dibutuhkan dalam penelitian.

2. Tabulasi data (pengelompokan)

Dalam hal ini, data yang di kelompokkan sesuai dengan variabel-variabel yang telah di kumpulkan di lapangan.

Penerapan data sesuai dengan pendekatan ilmiah pengolahan data yang telah di peroleh dengan menggunakan aturan-aturan yang ada sesuai dengan metode penelitian yang di gunakan. Dalam penerapan data ini, mengacu pada metode poenelitian kualitatif yang mana data di maksud akan di sajikan pada bab selanjutnya.

\footnotetext{
${ }^{8} \mathrm{Ibid}$, hal. 165

${ }^{9}$ Ibid, hal. 135

${ }^{10} \mathrm{Ibid}$, hal.103
} 
Didalam menganalisis data dalam hal ini penulis menggunakan metode induksi dan deduksi.

Metode deduksi adalah suatau jalan berpikir dari hal yang sifatnya umum kemudian dikenakan kepada suatu yang sifatnya khusus. Melalui metode ini penulis gunakan untuk mempelajari masalah-masalah yang sifatnya umum baru kemudian ditarik kesimpulan atau pengetahuan yang bersifat khusus.

Metode Induksi, kebalikan dari metode deduksi yang bersifat Induksi (induktif) adalah : "Berangkat dari fakta- fakta yang khusus, pristiwa-pristiwa yang kongkrit, kemudian fakta-fakta atau pristiwa-pristiwa yang khusus konkrit itu ditarik generalisasi-generalisasi yang mempunyai sifat umum. Jadi melalui metode yang bersifat induksi (induktif) ini diadakan penganalisaan data- data dari suatu hal yang sifatnya khusus terjadi, dianalisa melalui suatu pemikiran yang dapat memberikan suatu kesimpulan. ${ }^{11}$

\section{HASIL DAN PEMBAHASAN}

\section{A. Metode PAKEM dalam Meningkatkan Prestasi Belajar Kelas VI MI NW Karang} Baru Kecamatan Wanasaba Kabupaten Lombok Timur Tahun Pelajaran 2015/2016

Untuk mengetahui tingkat prestasi belajar siswa pada materi Qur'an Hadits Kelas VI MI NW Karang Baru dengan menggunakan metode PAKEM. Dari hasil observasi diperoleh data yang diperoleh dari hasil evaluasi belajar. Data-data tersebut selanjutnya dianalisis dengan menggunakan metode yang telah ditetapkan sebelumnya. Pendidikan di MI NW Karang Baru. dilaksanakan pada : Pada waktu kegiatan belajar mengajar di sekolah (pada jam pelajaran/ intrakurikuler)

Berdasarkan pembelajaran/rencana pelaksanaan pembelajaran telah menunjukkan kesudian antara tindakan yang diinginkan dalam penelitian ini, karena terbukti dalam proses pembelajaran tersebut, siswa termotivasi dalam menerima apa yang disampaikan oleh guru sehingga materi pembelajaran dengan materi menghafal surat-surat pendek dapat mudah dipahami serta aktif dalam menyelesaikannya.

\footnotetext{
${ }^{11}$ Ibid, hal.159
} 
Dalam pelaksanaan Bidang studi Qur'an Hadits di MI NW Karang Baru di laksanakan dengan metode pakem di gunakan oleh guru-guru yang ada, dalam hal penelitian di fokuskan pada metode pembelajaran PAKEM dalam upaya meningkatkan prestasi belajar di MI NW Karang Baru. ${ }^{9}$

Sebelum metode ini diterapkan nilai rata-rata siswa-siswi adalah 60,1 dan setelah metode ini diterapkan hasilnya bisa dikatakan lebih baik dari sebelumnya yakni rata-rata bisa mencapai standar kompetensi yang telah di buat oleh guru mata pelajaran yaitu 65,00.

Untuk lebih jelasnya nilai-nilai siswa-siswi itu dapat dilihat pada tabel :

Nilai pada semester pertama tahun ajaran 2015/2016 sebelum metode pembelajaran PAKEM di terapkan. ${ }^{10}$

Tabel 01

Kedaan Nilai siswa Kelas VI MI NW Karang Baru

Tahun Pelajaran. 2015/2016

\begin{tabular}{|c|l|c|c|}
\hline No & \multicolumn{1}{|c|}{ Nama Siswa } & Kelas & Nilai \\
\hline 1 & BASRI & VI & 60 \\
\hline 2 & ALYA ATMA LESTARI & VI & 60 \\
\hline 3 & ANGGA MALAYA SARI & VI & 64 \\
\hline 4 & ARIADI & VI & 50 \\
\hline 5 & BQ. NURUSSYIFA & VI & 63 \\
\hline 6 & EMI EFENDI & VI & 62 \\
\hline 7 & ERWIN YAHYA W & VI & 61 \\
\hline 8 & HAYATUNNUFUS & VI & 61 \\
\hline 9 & MUH. FATHUL YAQIN & VI & 50 \\
\hline 10 & MUH. HIDAYAT & VI & 63 \\
\hline 11 & MUH. IRFAN ROSADI & VI & 64 \\
\hline 12 & MUH. RIZWAN BUSYAIRI & VI & 64 \\
\hline 13 & MUH. ZAINUDDIN & VI & 40 \\
\hline 14 & NURHIDAYATULLAH & VI & 60 \\
\hline 15 & NURLAILI AZIZAH & VI & 70 \\
\hline
\end{tabular}

\footnotetext{
${ }^{9}$ Wawancara Guru Qur'an Hadit MI NW Karang Baru, 16 Juli 2015

${ }^{10}$ Dokumen Leger Siswa Kelas VI MI NW Karang Baru, 15 Juli 2015
} 


\begin{tabular}{|c|l|c|c|}
\hline 16 & NURUL AINI & VI & 60 \\
\hline 17 & RUHIATUL ADAWIYAH & VI & 60 \\
\hline 18 & YUNI APRILIANA & VI & 60 \\
\hline \multicolumn{2}{|c|}{ Nilai rata-rata } & 60,08333 \\
\hline
\end{tabular}

Nilai pada semester dua tahun pelajaran 2015/2016 setelah metode pembelajaran PAKEM di terapkan. ${ }^{11}$

Tabel 02

Kedaan Nilai siswa Kelas VI MI NW Karang Baru

Tahun Pelajaran. 2015/2016

\begin{tabular}{|c|l|c|c|}
\hline No & \multicolumn{1}{|c|}{ Nama Siswa } & Kelas & Nilai \\
\hline 1 & BASRI & VI & 65 \\
\hline 2 & ALYA ATMA LESTARI & VI & 65 \\
\hline 3 & ANGGA MALAYA SARI & VI & 64 \\
\hline 4 & ARIADI & VI & 60 \\
\hline 5 & BQ. NURUSSYIFA & VI & 66 \\
\hline 6 & EMI EFENDI & VI & 65 \\
\hline 7 & ERWIN YAHYA W & VI & 66 \\
\hline 8 & HAYATUNNUFUS & VI & 65 \\
\hline 9 & MUH. FATHUL YAQIN & VI & 68 \\
\hline 10 & MUH. HIDAYAT & VI & 63 \\
\hline 11 & MUH. IRFAN ROSADI & VI & 70 \\
\hline 12 & MUH. RIZWAN BUSYAIRI & VI & 75 \\
\hline 13 & MUH. ZAINUDDIN & VI & 68 \\
\hline 14 & NURHIDAYATULLAH & VI & 60 \\
\hline 15 & NURLAILI AZIZAH & VI & 80 \\
\hline 16 & NURUL AINI & VI & 70 \\
\hline 17 & RUHIATUL ADAWIYAH & VI & 65 \\
\hline 18 & YUNI APRILIANA & VI & 66 \\
\hline & & & Nilai rata-rata \\
\hline
\end{tabular}

Sumber : Data ini dikutip dari data hasil semester di MI NW Karang Baru

\footnotetext{
${ }^{11}$ Dokumen Leger Siswa Kelas VI MI NW Karang Baru, 15 Juli 2015
} 


\section{B. Kendala-Kendala Penerapan Metode Pakem Terhadap Prestasi Belajar Qur'an Hadits Kelas VI MI NW Karang Baru Kecamatan Wanasaba Kabupaten Lombok Timur Tahun Pelajaran 2015/2016}

Dalam kegiatan belajar mengajar, memang tidak selalu bisa berjalan dengan lancar (all round), tetapi kadang-kadang terdapat hambatan-hambatan atau fenomena-fenomena yang menyebabkan tujuan-tujuan yang sudah ditetapkan tidak dapat terlaksana.
a. Orang tua sibuk dengan pekerjaannya
b. Orang tua buta huruf tidak mengerti rafort
c. Sulit bertemu bersama guru atau wali kelas
d. Orang tua selalu mengharapkan pendidikan anaknya hanya di sekolah saja
e. Orang tua selalu yakin akn keberhasilan anaknya.12

Faktor internal merupakan aspek-aspek yang melekat secara individual pada keperibadian anak didik, baik yang bersifat rohani maupun bersifat jasmaniah, dimana pada umumnya yang bersifat rohani merupakan sifat-sifat yang terbawa sejak lahir. Lingkungan pada wahana ini pada umumnya hanya berperan untuk mengoptimalisasi seseorang untuk berbuat yang lebih baik sesuai dengan kualitas karaktristik tindakan-tindakan dimaksud. ${ }^{13}$

Adanya perbedaan atau kesenjangan yang terjadi didalam rumah tangga juga dapat berpengaruh terhadap prestasi belajar anak itu sendiri. Sarana dan prasarana gedung sekolah yang tidak memadai itulah yang menyebabkan minat belajar siswa yang masih kurang. Minat terhadap sesuatu merupakan hal yang sangat penting untuk di ketahui oleh guru karena dengan adanya minat siswa terhadap mata pelajaran yang kita berikan, maka isi dari materi pelajaran tersebut diserap dengan baik.

Sebaliknya tanpa adanya minat terhadap apa yang kita berikan dengan susahpayah yang tidak akan didengar, apalagi dikuasai oleh siswa. Maka unsurunsur yang dapat menarik minat siswa di sekolah dapat berupa bahan pelajaran, alat-alat pelajaran yang digunakan, situasi kelas, dan lingkungan, bahkan gurunya

\footnotetext{
${ }^{12}$ Muh. Nazri, S.Pd.I, Kepala MI NW Karang Baru, Wawancara, 16 Juli 2015

${ }^{13}$ Guru MI NW Karang Baru, Wawancara, 9 Juli 2015
} 
sendiri apabila siswa mempunyai minat terhadap sesuatu maka seluruh daya, jiwa, akan dicurahkan pada apa yang sedang diperhatikan. ${ }^{14}$

Demikian di antara problematika yang dihadapi orang tua dalam meningkatkan prestasi belajar mengajar di MI NW Karang Baru Desa Karang Baru Kecamatan Wanasaba Kabupaten Lombok Timur.

\section{Upaya-upaya yang dilakukan untuk mengatasi Penerapan Metode Pakem} Terhadap Prestasi Belajar Qur'an Hadits Kelas VI MI NW Karang Baru Kecamatan Wanasaba Kabupaten Lombok Timur Tahun Pelajaran 2015/2016

Upaya-upaya terhadap konsep dalam peningkatan prestasi belajar siswa baik yang dilakukan para guru dalam mendidik anak di sekolah maupun yang dilakukan oleh keluarga dalam usaha meningkatkan prestasi belajar anak di sekolah yang di berikan oleh kelurga di rumah.

Usaha para guru dalam mengembangkan prestasi belajar anak di sekolah. Prestasi belajar yang tinggi bagi para anak didik di sekolah merupaka simbol kemajuan yang dicapai sekolah tersebut, karena itu upanya pengembangan prestasi ini perlu di usahakan secara kontineu dan terus menerus serta berkesenambungan.

Orang tua dapat berperan sebagai pasilitator dan pencipta suasana belajar yang menyenangkan bagi anak dan motivator yang merangsang semangat belajar anak sehingga dapat mendongkrak prestasi belajar siswa di madrasah.

Upaya-upaya orang tua dalam membantu anak mencapai prestasi belajar anaknya dapat dilakukan dengan cara sebagai berikut ;

a. Mengontrol kegiatan bermain anak

b. Mengontrol nilai raport anak

c. Mengontrol jam belajar anak

d. Konsultasi dengan guru/wali kelas anak mengenai perkembangan anak

e. Membina disiplin dan pembiasaan belajar anak di rumah

f. Memberikan refard atau pujian dan penghargaan atas prestasi belajar yang dicapainya. ${ }^{15}$

Partisivasi orang tua dalam meningktkan prestasi belajar Qur'an hadits baik pada peningkatan sekolah maupun keluarga faktor terpenting yang harus di perhatikan para anggota keluarga adalah mempertinggi prestasi anak. Sebab

${ }^{14}$ TU MI NW Karang Baru, Wawancara, 7 Juli 2015

${ }^{15}$ H. Makki, Wali Murid, Wawancara, tanggal 16 Juli 2015 
prestasi ini merupakan tolak ukur kemajuan suatu pendidikan terutama dalam usaha meningkatkan mutu dan kualitas pendidikan.

Usaha-usaha terhadap konsep dalam peningkatan prestasi belajar siswa baik yang dilakukan para orang tua dan guru dalam mendidik anak di sekolah maupun yang dilakukan oleh keluarga dalam usaha meningkatkan prestasi belajar anak di sekolah yang di berikan oleh kelurga di rumah.

Orang tua dapat berperan sebagai pasilitator dan menyampaikan suasana belajar yang menyenangkan bagi anak dan motivator yang merangsang semangat belajar anak sehingga dapat mendongkrak prestasi belajar siswa di madrasah.

Partisivasi orang tua dalam membantu anak mencapai prestasi belajar anaknya dapat dilakukan dengan cara sebagai berikut ;

a. Proaktif memberikan dukungan kegiatan intra dan exstrakurikuler yang diselenggarakan oleh madrasah

b. Menyiapkan guru pripat/tutor dalam memperdalam materi pembelajaran di sekolah/madrasah. ${ }^{16}$

Perlu dimaklumi bahwa didalam proses intraksi mengajar orang tua minimal memiliki tiga modal, yaitu : kemampuan medesain lingkungan kemampuan mengkomunikasikan kepada anak dan mampu menjaga serta menampakkan nilai-nilai moral seorang yang dedukatif kepada anak-anak mereka.

Berbicara tentang faktor terpenting bagi seorang keluarga peribadian. Keperibadian itulah yang akan menentukan apakah ia menjadi pendidik dan pembina yang baik bagi anak didiknya, ataukah ia menjadi perusak atau penghancur bagi hari depan anak didik, terutama bagi anak didik yang masih kecil (tingkat sekolah dasar) adap mereka sedang mengalami kegoncangan jiwa (tingkat menengah).

\section{Pembahasan}

Proses belajar mengajar adalah suatu proses yang ditandai dengan adanya perubahan pada diri seseorang. Perubahan sebagai hasil dari berbagai bentuk seperti: perubahan, pemahaman, sikap tingkah laku, keterampilan,

\footnotetext{
${ }^{16}$ Muh. Nazri, S.Pd.I, Kepala MI NW Karang Baru, Wawancara, 16 Juli 2015
} 
kecakapan, kebiasaan, serta perubahan aspek-aspek yang lain yang ada pada indviidu yang belajar.

Dari pengertian belajar yang di atas dapat di pahami bahwa setiap proses pembelajaran yang di lakukan oleh guru dan siswa pada saat jam pembelajaran selalu bertitik tolak pada satu tujuan yakni perubahan. Perubahan yang dimaksud disini adalah perubahan hasil misalnya perubahan pemahaman:dari tidak paham jadi memahami masalah yang di pelajari baik saat belajar maupun setelah selesai belajar, tentang alam secara sistematis: sebelum mempelajari suatu masalah misalnya dalam hal ini bidang studi Qur'an Hadits tentang patriotisme dimana dalam pembahasan permasalahan ini sebelum belajar tidak memiliki jiwa patriotisme dalam dirinya kemudian setelah mempelajari tentang patriotisme ada tentang alam secara sistematis yang menunjukkan jiwa patriotisme, perubahan alam : terjadi perubahan alam misalnya sebelum mempelajari tentang aktviitas yang terjadi pada alam masih belum terbayang dalam hal melakukan prakik kemudian setelah mempelajari terjadi perubahan dalam hal ini, perubahan kemampuan: disini terjadi perubahan kemampuan setelah mempelajari masalah teknologi menjadi lebih cakap dan mahir menggunakan teknologi terbaru yang ada, perubahan kebiasaan: terjadi perubahan kebiasaan setelah misalnya dalam pembahasan masalah sosial sebelumnya kebiasaannya sering menimbulkan masalah sosial contohnya membuang sampah semabarangan kemudian setelah mempelajari pembahasan ini terjadi perubahan kebiasaan tidak membuang sampah sembarangan.

Untuk mencapai perubahan-perubahan itu yang dalam hal ini bisa diukur dari peningkatan aktivitas dan prestasi belajar dari siswa-siswi MI NW Karang Baru diperlukan suatu metode pembelajaran yang lebih efektif dan efisien dalam proses pembelajaran yang berlangsung.

Metode pembelajaran PAKEM adalah salah satu metode yang diterapkan untuk meningkatkan prestasi belajar. Dalam setiap SK KD yang sesuai dimana metode pembelajaran ini bisa diterapkan, karena tidak semua materi atau pokok bahasan bisa menerapkan metode ini walaupun sebagian besar materi Bidang studi Qur'an Hadits yang ada bisa menerapkan metode ini. Metode pembelajaran PAKEM sendiri merupakan metode pembelajaran yang berupaya menanamkan dasar-dasar berfikir ilmiah pada diri siswa, sehingga dalam proses pembelajaran ini siswa lebih banyak belajar sendiri, mengembangkan kreativitas dalam 
memecahkan masalah. Siswa benar-benar ditempatkan sebagai subjek yang belajar. Peranan guru dalam pembelajaran dengan metode PAKEM adalah sebagai pembimbing dan fasilitator. Tugas guru adalah memilih masalah yang perlu disampaikan kepada kelas untuk dipecahkan. Namun dimungkinkan juga bahwa masalah yang akan dipecahkan dipilih oleh siswa. Tugas guru selanjutnya adalah menyediakan sumber belajar bagi siswa dalam rangka memecahkan masalah. Bimbingan dan pengawasan guru masih diperlukan, tetapi intervensi terhadap kegiatan siswa dalam pemecahan masalah harus dikurangi.

Walaupun dalam praktiknya aplikasi metode pembelajaran PAKEM sangat beragam, tergantung pada situasi dan kondisi sekolah, namun dapat disebutkan bahwa pembelajaran dengan metode PAKEM memiliki 5 komponen yang umum yaitu :

Question. Pembelajaran biasanya dimulai dengan sebuah pertanyaan pembuka yang memancing rasa ingin tahu siswa dan atau kekaguman siswa akan suatu fenomena.

Student Engangement. Dalam metode PAKEM, keterlibatan aktif siswa merupakan suatu keharusan sedangkan peran guru adalah sebagai fasilitator.

Cooperative Interaction. Siswa diminta untuk berkomunikasi, bekerja berpasangan atau dalam kelompok, dan mendiskusikan berbagai gagasan.

Performance Evaluation. Dalam menjawab permasalahan, biasanya siswa diminta untuk membuat sebuah produk yang dapat menggambarkan pengetahuannya mengenai permasalahan yang sedang dipecahkan.

Variety of Resources. Siswa dapat menggunakan bermacam-macam sumber belajar, misalnya buku teks, website, televisi, video, poster, wawancara dengan ahli, dan lain sebagainya.

\section{Simpulan}

Peningkatan prestasi belajar di MI NW Karang Baru Kecamatan Wanasaba Kabupaten Lombok Timur bisa di capai dengan menerapkan metode pembelajaran PAKEM karena metode pembelajaran ini merupakan metode pembelajaran yang berupaya menanamkan dasar-dasar berfikir ilmiah pada diri siswa, sehingga dalam proses pembelajaran ini siswa lebih banyak belajar sendiri, mengembangkan kreativitas dalam memecahkan masalah. Siswa benar-benar ditempatkan sebagai 
subjek yang belajar. Penerapan motode PAKEM dalam meningkatkan aktivitas dan prestasi belajar dalam pembelajaran dengan metode PAKEM adalah sebagai pembimbing dan fasilitator. Tugas guru adalah memilih masalah yang perlu disampaikan kepada kelas untuk dipecahkan. Namun dimungkinkan juga bahwa masalah yang akan dipecahkan dipilih oleh siswa. Tugas guru selanjutnya adalah menyediakan sumber belajar bagi siswa dalam rangka memecahkan masalah. Bimbingan dan pengawasan guru masih diperlukan, tetapi intervensi terhadap kegiatan siswa dalam pemecahan masalah harus dikurangi.

Sehingga dengan aktifitas yang di lewati oleh siswa-siswi pada saat proses pembelajaran dengan metode pembelajaran PAKEM mereka mendapatkan banyak sekali pengalaman baru karena mereka langsung mengalami sendiri dan mempraktikkan setiap materi pembelajaran yang di ajarkan oleh bapak dan ibu guru mereka di sekolah. Dalam metode pembelajaran siswa-siswi lebih aktif, siswa benarbenar ditempatkan sebagai subjek yang belajar. Guru hanya bertugas sebagai pembimbing dan fasilitator yang meyiapkan sumber belajar yang aké lakan siswa sebagai bahan pemecahan masalah yang akan di selesaikan.

\section{DAFTAR PUSTAKA}

Abu Ahmadi, Dasar-Dasar Praktik Mengajar, Semarang : CV Toha Putra., 1998 Agriawan, Belajar Yang Menyenangkan Sebuah Prosedur, Jakarta, Gema Media, 2001

Ali Muhammad Guru Dalam Proses Belajar Mengajar. Bandung : Sinar Baru Algensindo, 2002

Arikunto Suharsimi. Prosedur Penelitian Suatu Pendekatan Praktek, Edisi Revisi. Jakarta : Rineka Cipta 2002

Azra Izyumardi. Pendidikan Islam. Bandung : Remaja Rosdakarya, 2002.

Depag RI, 2007, Al-Qur'an dan Terjemah, CV. Samara Mandiri, Jakarta

Djamrah Syaiful Bahri. Prestasi Belajar dan Kompetensi Guru. Surabaya : Usaha Nasional, 1994

Poerwadarminta W.J.S. 1999. Kamus Umum Bahasa Indonesia. Jakarta : Balai Pustaka

Mulyasa. 2004. Kurikulum Berbasis Kompetensi. Konsep, Karakteristik, dan Implementasinya. Bandung : Remaja Rosdakarya

Muhibbin Syah. Ilmu Pendidikan dan Perubahan Sosial Teori pendidikan Pelaku Sosial Kreatif. Rake Sorasin, 1999 
Moleong Lexy J. Metodologo Penelitian Kualitatif, Bandung : Rosdakarya Offset, 2002

Margono, S. Metodologi Penelitian Pendidikan, Jakarta Rineka Cipta, Jakarta, 2004

Nasution, S, Didaktik Asas-asas Mengajar, Jemmars, Bandung, 1982

Rusyanto Hamid, Cara Belajar Menyenangkan, Depdikbur, Jakarta, 2001

Sudjana Nana Sudjana, Penilaian Peroses Belajar Mengajar, Bandung PT Reamaja Rosda Karya, 1989

Slameto. Belajar dan Faktor-Faktor Yang Mempengaruhinya. Jakarta : Rineka Cipta, 2003

Suryabrata, Sumadi, Psikologi Pendidikan, Raja Grafindo Persada, Jakarta, 1980

UUSPN No. 20 Tahun 2003 Berikut Penjelasannya. Jakarta : Cemerlang,

Usman M. Uzer. 2002. Menjadi Guru Professional. Bandung : Rosdakarya Offset, 2002

Zakiah Drajat dkk. Ilmu Pendidikan Islam. Jakarta : Bumi Aksara, 1996 